\title{
KNOWLEDGE OF STYLISTIC AND SYNTACTIC FEATURES OF COMPLEX SENTENCES IN THE MARI LANGUAGE AS A COMPONENT OF LANGUAGE EDUCATION (THE CASE OF PARALLELISM)
}

\author{
Galina L. Sokolova ${ }^{1}$, Anna L. Kolyago ${ }^{2 \star}$ \\ ${ }^{1}$ Assos. Prof., Mari State University, Russia, askgalinasokol@mail.ru \\ ${ }^{2}$ Assos. Prof., Mari State University, Russia, kolyago@yandex.ru \\ ${ }^{*}$ Corresponding Author
}

\begin{abstract}
At the present stage of development of society, the term language education has become very popular and relevant. Along with such important practical tasks as language and speech acquisition, language education contributes to self-development and personal development. At the same time, language education in the field of the native language is based on its literary norm. It involves the possession of a set of theoretical knowledge of the language and the ability to apply them effectively in different areas of language activity. Knowledge of the stylistic and syntactic features of the native language is an integral part of language education and gives its speakers the opportunity to understand their native language better, fully master the communicative language competence and form a language personality. The ability to use complex sentences in speech indicates that a person has a high level of language competence.

The article deals with parallelism as one of the effective stylistic figures of expressive syntax in a complex sentence in the Mari language. Analysis of sources from the works of Mari fiction has shown that complex sentences in the Mari language have a rich stylistic potential. In order to give the narrative imagery and expressiveness, authors often use structural parallelism. In complex, compound and conjunctionless complex sentences, expressiveness is created by structures with parallel repetition of grammatically homogeneous aspectual-temporal forms of verbs-predicates, various types of pronouns, mostly personal and demonstrative, conjunctions, conjunction words, and lexical elements related to autonomous parts of speech. Syntactic parallelism can be full or partial, depending on the order of repeated models in the sentence. Mari writers, poets and publicists, in order to enhance imagery and emotion, introduce other syntactic figures of speech in their works, along with structural parallelism. The stylistic figure of parallelism is widely used in the Mari language in works of fiction in the language of prose, poetry and journalism. The preferred choice of a particular stylistic means or figure of speech to show expression, evaluation or emotion is directly related to the author's intentions and goals.
\end{abstract}

Keywords: language education, language competency, Mari language, syntax, stylistics, complex sentence, expressivity, figures of speech, parallelism

\section{INTRODUCTION}

The Mari language belongs to the Finno-Ugric family of Uralic languages. Until the second half of the XVIII century, the language did not have a written language, then, with its appearance, foreign scientists began to 
study the language. Russian and Mari researchers began to study the Mari language later. The first works on the Mari language were devoted mainly to the study of phonetic and morphological features of the language. The syntax of the Mari language, as an object of research and description, is first mentioned in the work of the German researcher F. J. Wiedemann, who distinguished simple and complex sentences at that time. The theoretical foundations of the syntax of the Mari language are beginning to be laid in the works of V. M. Vasiliev and V. G. Sokolov. Mari linguists began to study syntax actively in the 60 s of the last century. Great contribution to the development of the theory of syntax in that period of time was made by the works of such prominent linguists as V. T. Timofeev, L. P. Vasikova, Z. V. Uchaev, N. I. Isanbayev, I. S. Galkin, F. I. Gordeev, Yu. V.Anduganov, G. N. Valitov.

Syntactic stylistics, which deals with expressive possibilities of word order, types of sentences, and syntactic connection types, became the subject of study in the 80 - ies of the last century. The stylistic potential of syntax is reflected in the thesis of N. N. Glukhova "the Language of Mari spells and prayers" (Glukhova, 1997). In her work, the scientist shows the richness of expressive possibilities of the Mari syntax by the example of spells and prayers. Syntactic figures of speech play an important role in creating imagery and expressiveness. Thesis of L. A. Abukayeva " Expressive syntactic constructions in the Mari language "(Abukayeva, 2005) and the monograph" Syntactic phraseologisms in the Mari language " (Abukayeva, 2005) reveal the stylistic potential of phraseological constructions that form the body of expressive syntactic constructions. N. M. Krasnova considered the parallelism of verb-noun phrases in the Mari language (Krasnova, 2003). Our work continues a series of articles on the problem of stylistic syntax (Sokolova, Kolyago 2019 a; 2019 b; 2020) and will be devoted to syntactic parallelism in complex sentences of different types.

\section{MATERIALS AND METHODS}

Insufficient knowledge and elaboration of the question of stylistic potential and expressive possibilities of syntax in complex sentence in the Mari language determine the relevance of the research. The expressive possibilities of syntactic parallelism in a complex sentence, as one of the productive figures of stylistics, are considered on the example of the language of fiction. The purpose of the research is to analyze the possibilities and features of using of syntactic parallelism in different types of complex sentences in the Mari language. The structural-semantic method, the method of synchronous description and analysis of the collected material are used in the research to achieve this goal. The tasks of the research follow from the goals and involve consideration of the expressive possibilities of syntactic parallelism in all its aspects in complex sentences in the language of fiction in the Mari language.

The object of the research is complex sentences of the Mari language in terms of their stylistic possibilities. In our research we will focus in detail on one of the stylistic figures of speech - syntactic parallelism, which creates expressiveness, imagery and emotionality of fiction. The possibilities of using the materials and results of the research in the practice of teaching the modern Mari language, as well as in the preparation of special courses on syntax of a complex sentence determine its practical significance and value.

\section{RESULTS}

The language of fiction has a rich stylistic potential. Stylistic features of the text, imagery and expressiveness of the narrative help to express stylistic figures of speech. One of these productive figures is considered to be parallelism, which occurs in the form of thematic, sound, and syntactic parallelism. Parallelism in linguistics is defined as - "... a rhetorical figure that represents the arrangement of identical or similar grammatical and semantic structure of speech elements in adjacent parts of the text, creating a single poetic image. Parallel elements can be sentences, their parts, phrases, words" ( https://ru.wikipedia.org/wiki/).

In our study, we will focus on syntactic parallelism, which is expressed in "uniform syntactic construction of phrases and their parts, the arrangement of sentence members in the same sequence" (Morin, Teterevnikova, 1960).

Parallelism in its various aspects is an integral part of the language of fiction and gives the text an imaginative of the narrative.

Communication, imagery and expressiveness are the main goals of structural parallelism in prose language. At the same time, in poetic works, a peculiar rhythm is created and connections are established between parts of poetic lines thanks to parallel constructions,. As N. I. Formanovskaya notes, " ... structural parallelism is based on uniformity and repetition. Therefore, the unity of purpose and modal-time plan in parts, the repetition of conjunctions, conjunctions and lexical elements is a prerequisite for structurally 
parallel figures" (Formanovskaya, 2015). Depending on the identity of the repeated constructions within the utterance, there is a distinction between full and partial parallelism, respectively. Full parallelism contains identical repeating models, and partial parallelism is uniform either at the beginning or at the end of syntactic unity.

\section{DISCUSSION}

Despite the fact that the written form of the Mari language is relative young, the language of fiction has a rich stylistic potential. To create imagery and emotionality, the authors use various syntactic figures in their works. N. N. Glukhova, who studied the language of Mari spells and prayers, calls syntactic figures "the Main means of ordering at the syntactic level..." (Glukhova,1997). The researcher defines parallelism as a technique that contributes to the creation of "order and symmetry of the text composition".

Parallelism in complex sentence is created by repeating verb-predicate forms, repeating pronouns, conjunctions, and lexical elements (Formanovskaya, 2015).

When repeating the vide-temporal and modal forms of predicate verbs, a special rhythm and melody of the narration is created, which attracts the reader's special attention. By repeating parallel constructions, complex sentence forms a single semantic unity. This type of repetition of parallel constructions in works of art in the Mari language is found in all types of complex sentences, for example: Чодыраште кенежымсыла йӱк-йӱан огеш шокто: кукуат огеш муралте, шӱшпыкат огеш шӱшкалте. 'There are no sounds in the forest like in summer: the cuckoo does not cuckoo, and the Nightingale does not sing' (Chavain, 1980).

Эрмак шуко вӥрым йоктарен, шуко сатум толен ... . 'Ermak shed a lot of blood, looted a lot of goods' (Chavain, 1980).

Кеч иктаж шовыч лийже ыле, вуетым кылдена ыле. 'If you even had a handkerchief, your head would be bandaged' (Chavain, 1980).

Кожлаш кайыдежат огеш лий, Рывыж луйыдежат огеш лий. 'one can't go to the forest and one can't shoot a Fox' (Smirnov-Semener, 2018).

N. M. Krasnova considered in the Mari language "... parallelism, in the formation of which verb-noun phrases partially participate within several sentences and noted the fact that in the Mari language this technique is most often implemented in complex sentences with a coordinating connection, for example: Кугурак ӱдырлан - кум пӧлеман оласе пачер, кевыт, а изи ӱдыржылан - ялысе полат. 'To the eldest daughter - a three-room city apartment, a shop, and to the youngest daughter-a village palace' (SmirnovSemener, 2018).

Теле кужун шуйна. Эрдене пычкемыш, кастене пычкемыш, а вара кужу-кужу йӱд. 'Winter lasts a long time. It is dark in the morning, it is dark in the evening, and then it is long, long night' (Smirnov-Semener, 2018).

Repetition of pronouns and other lexical units refers both to the syntactic and lexical-syntactic types of repetitions. According To N. I. Formanovskaya, such parallel constructions "... give the construction a strongly pronounced rhythm and accentuation" (Formanovskaya, p. 207). Just like the previous type of repetitions of parallel constructions, the repetition of pronouns in the Mari language can be both in compound, complex, and conjunctionless complex sentences, for example: - Колышт-ян, родем, теве мый мом шонышым: шич тый мыйын тупышкем, мый тыланет таза, пенгыде йолем дене полшем, тый мыланем таза, раш шинчат дене полшо. '-Listen, my dear, here's what I came up with: sit on my back, I'll help you with my strong legs, and you will help me with your healthy, sharp eyes (Chavain, 1980).

Тый пашам ыштен отыл, яра киймет дене шемемынат, пашам ыштет гын, тыят волгалтат ыле ... . 'You didn't work, you didn't turn black from work, if you worked, you would also become famous ...' (Chavain, 1980).

Шемшыдан але пеледеш: шемшыданг ана чевер ылчылан ош вынерла коеш. 'Buckwheat is still in bloom: the buckwheat field looks like a white canvas' (Chavain, 1980).

Нуно осал ен огытыл, нуно шкеат осал енлан верештыныт ала-мо? 'They are not evil people, they are probably caught by evil people' (Chavain, 1980).

Coordinating and subordinating conjunctions that are repeated in parallel constructions to connect parts of complex sentence are inherently heterogeneous. Their heterogeneity follows from the proper meaning of the conjunction that connects parts of a complex sentence. Coordinating conjunctions are means of conveying 
the semantic connection between parallel constructions, for example: Шошым рис латкок долларым шоген, а кызыт, у кинде шумеке, рис ныл долларым веле шога. 'In spring, rice cost twelve dollars, and now, when the crop is ripe, rice costs only four dollars' (Chawain, 1980).

Пашадар кӱсынымат шке шотын тӧрлаш пунчальыч: шофёрлан - машина, трактористлан — трактор, a ферме пашаенжылан - я туна, я ушкалым. 'We decided to settle the debt on a salary themselves: to the driver - the car, to the tractor driver - tractor and to the farm worker or bull or cow (Smirnov-Semener, 2018).

- Мланде йымал кугыжанышыш тӱрлӧ корно уло, иктыже кӧргашан тумо гоч эрта. Ты тумо тыглай огыл, а кумалме тумо, тудо мемнан Керемет отыштына шога. 'There are different roads to the underworld, one of them passes through a hollow in an oak tree. This oak is not simple, but a prayer oak, it stands in our witchcraft grove' (Sitnikov, 1996, No. 9).

Subordinating conjunctions, repeated within parallel constructions, add an additional expressive shade of concretization to the utterance, which comes from the meaning of the conjunction,

for example: Кунам чонышто кокытеланымаш илана, тунам Степан йодыш почеш йодышым шкаланже пуа, вашмутым кычалеш. 'When doubts are born in the soul, then Stepan asks himself a lot of questions and finds the answers' (Smirnov-Semener, 2018).

Вет пеш ожнак огыл пашаш тӱшкан лектыныт, рӱж тыршат ыле, мурат гын, чылан муралтен чӱчкалтат ыле, куштат гын, чылан кушталтен тавалтатыле. 'After all, quite recently they went to work together, tried together, if they sang, they all sang and whistled, if they danced, they all danced and danced' (Solovyov, 2018, No. 12).

When repeating conjunctions within the framework of structural parallelism, an expressive effect of emphasizing the described phenomenon or fact is created.

N. I. Formanovskaya rightly notes that the clearest sign of structural parallelism is the word order (Formanovskaya, p. 212). Thanks to the word order, the rhythm of the utterance is created and any of the sentence members is highlighted, for example: Юмыйӱла вет кок могыран: иктыже - айдемылан ӱшаным пуа, тудын кумылжым нӧлта, вийжым кугемда, весыже кӱшыл полышлан гына ӱшана, айдеме шке таптержым лунчыра, тыршымашыжым лыпландара. 'Belief in God is two-sided: on the one hand, it gives people hope, raises their spirits, increases their strength, on the other hand, it is only hope for the Supreme power, a person tries to calm himself' (Solovyov, 2018, No. 12.

N. N. Glukhova emphasizes the fact that "Parallel construction does not exist separately by itself" (Glukhova, 2015). In language, parallelism is reinforced by other stylistic figures, for example: Кереметлан кумалме ото энер серыпле улмаш, тудым чыкма дене авырыме, тушто кум могыр гыч пурымо капка лийын: иктыже, кече шичме могырно улшыжо, ен-влаклан пураш-лекташ ыштыме; весыже, кече нӧлтмӧ могырышто улшыжо, кумалтыш вольыкым пурташ келыштарыме; кумшыжо, кечылан мелын улшыжо, вйд пурташ лийын. 'The grove in which the devil was worshipped was fortified by a bank, it was fenced with a stockade, there was a gate that could be entered from three sides: one, the entrance from the sunset, was made for people; the other, from the sunrise, was adapted to launch sacrificial animals; the other was to bring water' (Sitnikov, 1996, No. 9).

\section{CONCLUSION}

Knowledge of the stylistic and syntactic features of a language determines the linguistic competence of a language personality and is an integral part of language education. Analysis of sources from the works of Mari literature has shown that complex sentences in the Mari language have a rich stylistic potential. In order to give the narrative imagery and expressiveness, the authors often resort to structural parallelism. In compound, complex, and conjunctionless complex sentences, expressiveness is created by structures with parallel repetition of homogeneous aspectual-temporal forms of verbs-predicates, various types of pronouns, mainly personal and demonstrative conjunctions, conjunction words, and lexical elements related to significant parts of speech. Structural parallelism can be complete or partial, depending on the order of repeated models in the statement. Mari writers, poets and publicists introduce other syntactic figures of speech along with structural parallelism in their works in order to enhance imagery and emotionality. The stylistic figure of structural parallelism is widely used in the Mari language in works of fiction in the language of prose, poetry, and journalism. The preferred choice of a particular stylistic means or figure of speech to show expression, evaluation, or emotionality is directly related to the author's intentions and goals. 


\section{ACKNOWLEDGEMENT}

This research was financially supported by RFBR and Government of the Mari El according to the research project No 19-412-120002 «Stylistic syntax of compound sentences in the Mari language.

\section{REFERENCE LIST}

Abukaeva, L.A. (2005). Expressive syntactic constructions in the Mari language. Abstract of the dissertation (p. 45). Yoshkar-Ola. http://cheloveknauka.com/ekspressivnye-sintaksicheskie-konstruktsii-vmariyskom-yazyke

Abukaeva, L.A. (2005). «Expressive syntactic constructions in the Mari language». - Yoshkar-Ola, 2005. $192 \mathrm{p}$.

Glukhova, N.N. (1997). The language of Mari spells and prayers. Abstract of the dissertation for the degree of doctor of Philology (p. 45). Yoshkar-Ola .

Glukhova, N.N. (2015). Syntactic stylistic means in Mari spells. Philological science. Questions of theory and practice. (P. 50-53). Tambov: Diploma, No. 6 (48): in 2 parts p. I.

Krasnova, N.M. (2003). The stylistic potential of verbal-nominal wordcombinations in the Hill Mari literary language. http://www.dslib.net/jazyki-mira/stilisticheskij-potencial-glagolno-imennyh-slovosochetanij-vgornomarijskom.html

Krylov, V. (1996). Чарка мут* Шочмо кече нерген. (Р. 111-114). Onychko. Mari publishing house. № 9.

Moren, M.K., Teterevnikova, N.N. (1960). Stylistics of the modern French language. (298 P). Publishing house of literature in foreign languages. Moscow.

Sitnikov, K,. (1996). Вувер. (Р. 63-70). Onychko. Mari publishing house. № 9.

Smirnov-Semener, В. (2008). Леве йӱр дечь вара. (Р. 6-53). Onychko. Mari publishing house. № 1.

Sokolova, G.L., Kolyago, A.L. (2019 a). Complex Sentences in the Mari Language. Proceedings of ADVED 2019- 5th International Conference on Advances in Education and Social Sciences. (P. 291-294). Istanbul, Turkey.

Sokolova, G.L., Kolyago, A.L. (2019 в). Stylistic Features of the Compound Sentence in the Mari Language. Proceedings of ADVED 2019- 5th International Conference on Advances in Education and Social Sciences. ( P. 295-298). Istanbul, Turkey.

Sokolova, G.L., Kolyago, A.L. (2020). Expressive ways of reporting other persons' spreech in the Mari language. (P. 51-54). Proceedings of INTCESS 2020- 7th International Conference on Education and Social Sciences. DUBAI (UAE).

Solovyov, V. (2018). Мырий сын: Ожно, кызыт, вара. (Р. 109-123). Onychko. Mari publishing house. № 12.

Chavain, S.G. (1980). Collected works in three books. 1. Poetry, prose. (318 p.). Yoshkar-Ola. Mari book publishing house.

Formanovskaya, N.I. (2015). Complex sentence: Semantic and stylistic aspects, 3rd ed. (240 p.). Moscow: LENAND. 